\title{
СУЧАСНІ ПІДХОДИ ДО ПРОФЕСІЙНОЇ ПІДГОТОВКИ КОМПЕТЕНТНИХ ФАХІВЦІВ ІЗ ЖУРНАЛІСТИКИ ТА СОЦІАЛЬНИХ КОМУНІКАЦІЙ
}

\author{
Дяченко І. М. \\ кандидат наук із соиіальних комунікаиій, дочент, \\ дочент кафедри журналістики та української філологї \\ Класичний приватний університет \\ вул. Жуковського, 70-Б, Запоріжжя, Украӥна \\ orcid.org/0000-0003-1240-3918 \\ irinadyachenko777@gmail.com
}

\begin{abstract}
Ключові слова: бакалавр, вищяа освіта, журналіст, компетентність, магістр, майбутній фахівецьь, професійна підготовка, сфера сочіальних комунікащій.
\end{abstract}

У статті розкрито наукові підходи до формування компетентності майбутніх фахівців із журналістики та соціальних комунікацій. Окреслено основні аспекти професійної підготовки майбутніх фахівців бакалаврського і магістерського рівнів за освітньою програмою «Журналістика та соціальні комунікації». Підкреслюється, що стан сучасної журналістики значно мірою визначається професійною компетентністю журналістів, розумінням ними своєї суспільної ролі й соціокультурної місії, ставленням до професії. Справжній професіонал-журналіст повинен володіти не лише комплексом загальних і спеціальних професійних здібностей, але й умінням творчо реагувати на політичні, економічні, соціально-культурні зміни у світі й бути при цьому конкурентоспроможним, компетентним у вирішенні професійних завдань, що все частіше виступає запорукою його успіху у фаховій діяльності. Зазначено, що формування компетентності майбутніх фахівців із журналістики та соціальних комунікацій, їхньої готовності застосовувати отримані знання, вміння та навички у професійних ситуаціях полягає в набутті студентами інтегральної, загальних та спеціальних компетентностей. Загальні компетентності фахівця із журналістики та соціальних комунікацій: перекладати державною мовою професійноспрямовану інформацію, аргументувати вибрані варіанти рішень і нести за них особисту відповідальність. Студента необхідно навчити пошуку, обробленню та аналізу інформації з різних джерел, здатності знаходити напрями саморозвитку, підвищення своєї кваліфікації та майстерності. У випускника університету спеціальності 061 «Журналістика» мають бути розвинені вміння аналізувати соціально-значущі проблеми та процеси, що відбуваються в суспільстві, й прогнозувати можливий розвиток їх у майбутньому. Необхідно сформувати навички використання інформаційних i комунікаційних технологій; усвідомлення небезпеки i загроз, що виникають у процесі професійної діяльності в медіа. Майбутні фахівці 3 журналістики та соціальних комунікацій повинні володіти навичками роботи 3 комп'ютером як засобом управління інформацією в глобальних соціальних мережах та засобами іiі захисту; здатністю працювати в міжнародному контексті. Особлива роль належить формуванню здатності до групової взаємодії під час вирішення проблем; здатності до самостійного прийняття рішень у непередбачуваних умовах. Важливими $€$ : здатність аналізувати і визначати ефективність використання сучасних напрямів розвитку інформаційних проектів; здатність зрозуміло доносити висновки та пояснення до аудиторії; здатність організовувати і проводити професійну діяльність у сфері соціальних комунікацій; здатність формувати інформаційний контент; здатність створювати інформаційний продукт; здатність ефективно просувати створений медійний продукт; здатність проводити дослідження для ефективного просування медійного продукту. 


\title{
MODERN APPROACHES TO PROFESSIONAL TRAINING OF COMPETENT PROFESSIONALS IN JOURNALISM AND SOCIAL COMMUNICATIONS
}

\author{
Diachenko I. M. \\ Candidate of Sciences in Social Communications, Associate Professor, \\ Associate Professor at the Department of Journalism and Ukrainian Philology \\ Classic Private University \\ Zhukovskoho str., 70-B, Zaporizhzhia, Ukraine \\ orcid.org/0000-0003-1240-3918 \\ irinadyachenko777@gmail.com
}

Key words: bachelor, higher education, journalist, competence, master, future specialist, professional training, sphere of social communications.

\begin{abstract}
The article reveals scientific approaches to the formation of competence of future specialists in journalism and social communications. The main aspects of professional training of future specialists of bachelor's and master's levels in the educational program are outlined: "Journalism and social communications". It is emphasized that the state of modern journalism is largely determined by the professional competence of journalists, their understanding of their social role and socio-cultural mission, attitude to the profession. A true professional journalist must have not only a set of general and special professional abilities, but also the ability to respond creatively to political, economic, socio-cultural changes in the world and be competitive, competent in solving professional problems, which is increasingly the key to his success. in professional activity. It is noted that the formation of competence of future specialists in journalism and social communications, their readiness to apply the acquired knowledge, skills and abilities in professional situations is General competencies of a specialist in journalism and social communications: to translate professionallyoriented information into the state language, to argue the chosen solutions and to bear personal responsibility for them. The student must be taught to search, process and analyze information from various sources, the ability to find areas of self-development, improving their skills and abilities. A graduate of the university majoring in 061 "Journalism" must have developed the ability to analyze socially significant problems and processes occurring in society, and predict their possible development in the future. the acquisition by students of integrated, general and special competencies. It is necessary to form skills of using information and communication technologies; awareness of the dangers and threats that arise in the process of professional activity in the media. Future professionals in journalism and social communications must have computer skills as a means of information management in global social networks and means of its protection; ability to work in an international context. A special role belongs to the formation of the ability to group interaction in solving problems; ability to make independent decisions in unpredictable conditions. Important are: the ability to analyze and determine the effectiveness of modern areas of information projects; ability to clearly communicate conclusions and explanations to the audience; ability to organize and conduct professional activities in the field of social communications; ability to generate information content; ability to create an information product; the ability to effectively promote the created media product; the ability to conduct research to effectively promote a media product.
\end{abstract}

У сучасних умовах стрімких змін і потужного розвитку соціально-комунікаційних технологій суспільство потребує конкурентоспроможного журналіста, здатного самостійно орієнтуватися в інформаційному просторі, аналітично мислити. Стан сучасної журналістики значно мірою визначається професійною компетентністю журналістів, розумінням ними своєї суспільної ролі й соціокультурної місії, ставленням до профеciï. Справжній професіонал-журналіст повинен не лише володіти комплексом загальних і спеціальних професійних здібностей, але й бути 
конкурентоспроможним, компетентним у вирішенні професійних завдань, що все частіше виступає запорукою його успіху в фаховій діяльності. Цим пояснюється актуальність порушеної проблеми.

Мета статті: розкрити наукові підходи до формування компетентності майбутніх фахівців із журналістики та соціальних комунікацій; окреслити основні аспекти професійної підготовки майбутніх фахівців бакалаврського і магістерського рівнів за освітньою програмою «Журналістика та соціальні комунікації».

Питанням професійної освіти присвятили велику кількість наукових досліджень багато вчених, зокрема А. Алексюк, С. Амеліна, С. Клепко, Н. Ничкало, Л. Сущенко тощо. Проблемі компетентнісного підходу до професійної підготовки майбутніх фахівців приділяли увагу О. Овчарук (світовий досвід та українські перспективи); Г. Сорокіна (формування функціональних компетентностей майбутніх фахівців зв’язку); В. Свистун, В. Ягупов (компетентісний підхід до підготовки фахівців у системі вищої освіти), А. Хуторський, С. Царькова (модернізація освіти на основі компетентнісного підходу); І. Зимня, О. Овчарук, О. Пометун (методи реалізації компетентнісного підходу в досвіді зарубіжних країн); О. Крисан, Ю. Татур (сутність компетентностей); О. Локшина, М. Савчин, О. Пащенко (моніторинг рівнів досягнення компетентностей) та інші. Проте, незважаючи на значну кількість наукових праць, що стосуються формування професійної компетентності, проблема формування компетентностей майбутніх фахівців із журналістики та соціальних комунікацій у процесі професійної підготовки потребує додаткової уваги.

У журналістському професіоналізмі «поєднуються такі не завжди сумісні риси, як комерційна кмітливість, підприємливість, творчі здібності й здатність бути організатором редакційного процесу, грунтовні загальні та професійні знання у поєднанні 3 високими моральними чеснотами, здатність глибоко та небанально мислити, виваженість та емоційний запал, бездоганне володіння словом» [2, с. 41].

Поняття «компетенізація освіти» експлікується як зміщення акценту 3 накопичування нормативно визначених знань, умінь і навичок до розвитку у студентів здатності практично діяти, застосовувати навички й досвід успішних дій у ситуаціях професійної діяльності та соціальної практики [3, с. 23]).

Відмінність компетентного фахівця від кваліфікованого полягає в тому, що перший не тільки має певний рівень знань, умінь, навичок, але і здатний реалізувати i реалізує їх у роботі. Компетентність передбачає наявність в індивіда внутрішньої мотивації до якісного здійснення своєї професійної діяльності, присутність професійних цінностей і ставлення до своєї професії як цінності. Компетентний фахівець здатний виходити за межі предмета своєї професії, він володіє деяким творчим потенціалом саморозвитку [9].

Загалом поняття компетентності містить набір знань, навичок і ставлень, що дає змогу особистості ефективно діяти або виконувати певні функції, спрямовані на досягнення стандартів у професійній галузі або певній діяльності [4, с. 8-9].

В організації професійної освіти представників Свропейського співтовариства особливе значення надається п'яти ключовим компетенціям: соціальній (здатність взяти на себе відповідальність, спільно виробляти рішення і брати участь у його реалізації, толерантність до різних етнокультур і релігій, прояв зв'язку особистих інтересів із потребами підприємства й суспільства); комунікативній (визначає володіння технологіями спілкування, усного та письмового спілкування різними мовами, в тому числі й комп'ютерного програмування, включаючи спілкування через Інтернет); соціально-інформаційній (характеризує володіння інформаційно-комунікаційними технологіями і критичне ставлення до соціальної інформації, яку поширюють засоби масової інформації); когнітивній (готовність до постійного підвищення освітнього рівня, потреба в актуалізації й реалізації свого особистісного потенціалу, здатність самостійно набувати нових знань і вмінь, здатність до саморозвитку); спеціальній (самостійне виконання професійних дій, оцінки результатів своєї праці) [1].

Згідно $з$ проєктом Тюнінг Свропейської Коміciї («Налаштування освітніх структур в Європі») запроваджується результатна парадигма освіти. В iї основі - імперативність навчального результату (результату освіти), який визначається в термінах компетентностей і є системоутворюючим фактором: йому підпорядковуються відповідні методи викладання та способи оцінювання успішності студентів. За змістом і роллю компетентності, що формуються в освіті, за проєктом поділяють на загальні (ключові) і специфічні (предметні) [12].

У положеннях Національної рамки кваліфікацій України відображено системний і структурований за компетентностями опис кваліфікаційних рівнів. Цю рамку створено з метою: введення європейських стандартів та принципів забезпечення якості освіти 3 урахуванням вимог ринку праці до компетентностей фахівців; забезпечення гармонізації норм законодавства у сфері освіти та соціально-трудових відносин; сприяння національному і міжнародному визнанню кваліфікацій, здобутих в Україні; налагодження ефективної взаємодії сфери освітніх послуг та ринку праці. Відповідно до Національної рамки кваліфікацій України розглядаються компетентності: інтегральна - узагальнений опис кваліфікаційного рівня, який виражає основні компетентнісні характеристики рівня щодо навчання та/або професійної 
діяльності; компетентності як здатність особистості до виконання певного виду діяльності, що виражається через знання, розуміння, уміння, цінності, інші особисті якості; результати навчання - компетентності (знання, розуміння, уміння, цінності, інші особисті якості), яких набуває та/або здатна продемонструвати особа після завершення навчання [7].

Учений В. Ягупов виокремлює такі складники компетентності: професійну компетентність, пов'язану з безпосередньою професійною діяльністю; соціальну компетентність, яка реалізується у вмінні співпрацювати, організовувати спільну діяльність колективу на досягнення цілей, брати на себе відповідальність за спільні результати; особистісну компетентність - здатність до саморозвитку, самовдосконалення, самореалізації, прагнення до постійного підвищення своєї освітньої компетентності $[11$, с. 6$]$.

У науковій площині поняття «професійна компетентність» має багато дефініцій, зокрема: «система особистісних якостей, знань і умінь, що зумовлюють високий рівень володіння професійними вміннями та навичками, $\epsilon$ способом продуктивної і творчої самореалізації фахівця у професійній діяльності, спрямованій на засвоєння, передачу і створення професійних цінностей та нових технологій обробки інформації» [9, с. 50]; «багатофакторне утворення, що уможливлює успішне здійснення професійної діяльності $[8$, с. 18]; готовність особистості мобілізувати власні ресурси (організовані в систему знань, умінь, здатності й особистісних якостей), які необхідні для ефективного вирішення професійних завдань у типових та нестандартних ситуаціях, що включає в себе ціннісні ставлення особистості до цих ситуацій [7, с. 198] тощо.

Формування професійної компетентності майбутніх фахівців із журналістики та соціальних комунікацій - одна з головних функцій журналістської освіти, яка потребує модернізації, як і всі системи вищої освіти.

Згідно з освітньо-професійною програмою вищої освіти першого (бакалаврського) рівня галузі знань 06 «Журналістика» спеціальності 061 «Журналістика» (освітня програма: «Журналістика та соціальні комунікації») Класичного приватного університету [5], формування компетентності майбутніх фахівців iз журналістики та соціальних комунікацій, їхньої готовності застосовувати отримані знання, вміння та навички у професійних ситуаціях полягає в набутті студентами інтегральної, загальних та спеціальних (фахових, предметних) компетентностей. Серед загальних виокремлено: здатність виражати державною мовою логічно, правильно, аргументовано, чітко побудовану усну та письмову мову; перекладати професійно-спрямовану інформацію, аргументувати вибрані варіанти рішень і нести за них особисту відповідальність; здатність до пошуку, оброблення та аналізу інформації з різних джерел; здатність спілкуватися іноземною мовою 3 представниками обраної професії; здатність критично оцінювати свої переваги та недоліки, визначати шляхи усунення недоліків; готовність до сприйняття та аналізу критичних зауважень і зміни особистого ставлення до процесів, явищ, якщо це сприяє розвитку справи; здатність до різнобічного обговорення ситуацій, що призводять до конфлікту професійних інтересів; здатність знаходити напрями саморозвитку, підвищення своєї кваліфікації та майстерності; вміння аналізувати соціально-значущі проблеми та процеси, що відбуваються в суспільстві, і прогнозувати можливий розвиток їх у майбутньому; навички використання інформаційних і комунікаційних технологій; усвідомлення небезпеки і загроз, що виникають у процесі професійної діяльності в медіа; дотримання основних вимог інформаційної безпеки, захисту державної та комерційної таємниці; застосування основних методів, способів і засобів отримання, зберігання, обробки інформації; навички роботи з комп'ютером як засобом управління інформацією в глобальних соціальних мережах та засобами іiі захисту; здатність працювати в міжнародному контексті; здатність до адаптації та дії в новій ситуації; здатність до провадження безпечної діяльності; здатність спілкуватися з представниками інших професійних груп різного рівня (з експертами 3 інших галузей знань і видів соціокомунікативної діяльності), створювати стандартні теоретичні та соціокомунікативні моделі, аналізувати і змістовно інтерпретувати отримані висновки на основі опису соціокомунікативних процесів і явищ під час проведених досліджень; презентувати отримані результати; здатність працювати в команді; здатність до міжособистісної взаємодії; здатність працювати автономно; здатність діяти соціально відповідально та свідомо; здатність цінувати та поважати різноманітність і мультикультурність; здатність навчатися й оволодівати сучасними знаннями [5].

Особлива роль у професійній підготовці фахівців із журналістики та соціальних комунікацій належить формуванню спеціальних (фахових, предметних) компетентностей, таких як: здатність застосовувати знання зі сфери соціальних комунікацій у своїй професійній діяльності (мислити творчо, діалектично; вивчати та оцінювати стан соціально-комунікаційних відносин на всіх інформаційних рівнях; порівнювати та об'єктивно оцінювати різні системи соціально-комунікаційних відносин; досліджувати соціально- комунікаційні процеси i явища); здатність ефективно формувати комунікаційну стратегію; здатність до групової взаємодії під час вирішення проблем; здатність до самостійного прийняття рішень у непередбачуваних умовах; здатність аналізувати і визначати ефективність використання сучасних напрямів розвитку інформаційних 
проектів; здатність зрозуміло доносити висновки та пояснення до аудиторії; здатність організовувати і проводити професійну діяльність у сфері соціальних комунікацій; здатність формувати інформаційний контент; здатність створювати інформаційний продукт; здатність ефективно просувати створений медійний продукт; здатність проводити дослідження для ефективного просування медійного продукту тощо [5].

До переліку компетентностей випускника магістерського рівня спеціальності 061 «Журналістика» (освітняпрограма«Журналістикатасоціальнікомунікації») [6] належать такі: інтегральна компетентність (здатність розв’ язувати складні завдання і проблеми у певній галузі професійної діяльності або у процесі навчання, що передбачає проведення досліджень та/ або здійснення інновацій та характеризується невизначеністю умов і вимог); загальні компетентності (здатність до абстрактного мислення, аналізу та синтезу; здатність планувати час та управляти ним; здатність генерувати нові ідеї (креативність); здатність використовувати іноземні мови у популяризації своєї дослідницької та/або інноваційної роботи; вміння виявляти та вирішувати проблеми; здатність приймати обгрунтовані рішення; здатність розробляти проекти та управляти ними; здатність виявляти ініціативу та підприємливість; здатність оцінювати та забезпечувати якість виконуваних робіт); спеціальні (фахові, предметні) компетентності (здатність використовувати спеціалізовані концептуальні знання із соціальних комунікацій, набуті у процесі навчання та/або професійної діяльності на рівні новітніх досягнень в інноваційній діяльності та/або дослідницькій роботі; здатність критично осмислювати проблеми у професійній діяльності чи дослідницькій роботі на межі предметних галузей; здатність виконувати складні завдання і вирішувати складні проблеми, що потребує оновлення та інтеграції знань, часто в умовах неповної чи недостатньої інформації та суперечливих вимог; здатність проводити дослідницьку та/ або інноваційну діяльність у галузі соціальних комунікацій; здатність зрозуміло і недвозначно доносити власні висновки, а також знання та пояснення, що їх обгрунтовують, до фахівців і нефахівців, зокрема до осіб, які навчаються; здатність приймати рішення у складних і непередбачуваних умовах дослідницької та/або інноваційної роботи, що потребує застосу- вання нових підходів та прогнозування; здатність показувати свою відповідальність за розвиток професійного знання і практик та давати оцінку стратегічному розвитку команди; здатність до планування подальшого автономного та самостійного навчання у сфері дослідницької та/або інноваційної діяльності) [там само].

На думку О. Пометун, спираючись на зарубіжний досвід щодо впровадження компетентнісного підходу у професійну підготовку майбутніх фахівців, для будь-якої країни є корисним «порівнювати міжнародний і національний досвіди як розвитку освітньої системи загалом, так і можливостей для запровадження компетентнісного підходу зокрема; повне копіювання будь-яких освітніх моделей і феноменів інших країн $\epsilon$ непродуктивним; національні моделі освіти слід розбудовувати, керуючись національними потребами й особливостями» $[4$, с. 16$]$.

Висновки і пропозиції. Професійна підготовка майбутніх фахівців із журналістики та соціальних комунікацій $є$ процесом не лише опанування досвідом майбутньої професійної діяльності, а й особистісного та професійного розвитку. Компетентний журналіст завжди орієнтується на майбутнє, самоосвіту, передбачає зміни. Особливістю професійних компетентностей є те, що вони реалізуються в цей час і спрямовані на перспективу, що зумовлює потребу в пошуку нових підходів, впровадження інноваційних освітніх технологій, вдосконалення організаційно-методичного забезпечення підвищення якості підготовки фахівців для медіа. Майбутнє сучасного інформаційного суспільства значною мірою залежить від професійної компетентності фахівців із журналістики та соціальних комунікацій, від їхньої готовності до виконання свого призначення, функцій і соціальних ролей. Сьогодні український соціум потребує таких працівників засобів масової інформації з високим рівнем професійної компетентності, журналістської та загальної культури, з багатством духовних цінностей, зі свіжими, неординарними підходами до актуальних проблем сьогодення, які здатні до самореалізації в умовах жорсткої конкуренції у площині ринкових відносин, до критичного мислення, до формування громадської думки на діалогічних засадах і на принципах гуманізму, до оперативного реагування на перманентні зміни в усіх сферах життя.

\section{ЛІТЕРАТУРА}

1. Алексюк А.М. Педагогіка вищої освіти України. Історія. Теорія : підручник. Київ : Либідь, 1998. $560 \mathrm{c}$.

2. Здоровега В. Свропейський вибір: що брати з минулого, а чого вчитися українським 3МІ. Про журналістику і журналістів: статті, есе, виступи. Львів : ВЦ ЛНУ ім. І. Франка, 2004. № 3 (27). 141 с.

3. Клепко С.Ф. Філософія освіти в європейському контексті : монографія. Полтава : ПОІППО, 2006. $328 \mathrm{c}$.

4. Компетентнісний підхід у сучасній освіті: світовий досвід та українські перспективи / за заг. ред. О.В. Овчарук. Київ : К.І.С., 2004. 112 с. 
5. Освітньо-професійна програма вищої освіти першого (бакалаврського) рівня галузі знань 06 «Журналістика» спеціальності 061 «Журналістика». Запоріжжя : Класичний приватний університет, 2018. URL: http://virtuni.education.zp.ua/info_cpu/node/2742 (дата звернення: 05.12.2020).

6. Освітньо-професійна програма вищої освіти другого (магістерського) рівня галузі знань 06 «Журналістика» спеціальності 061 «Журналістика». Запоріжжя : Класичний приватний університет, 2018. URL: http://virtuni.education.zp.ua/info_cpu/node/2742 (дата звернення: 05.12.2020). .

7. Рогова Т.В. Розвиток професійно-педагогічної компетентності вчителя: методичний аспект. Засоби навчальної та науково-дослідної роботи : зб. наук. пр. Харків, 2004. Вип. 21. С. 197-206.

8. Сорокіна Г. Формування функціональних компетентностей майбутніх фахівців зв'язку. Вища освіта. 2009. № 12. С. 34-39.

9. Сысоев В.В., Сысоев И.В. Теоретические основы психологии управления : учебное пособие. Москва : Изд-во СГУ, 2006. С. 394.

10. Таизова O.C. (2015). Компетенция (основные смысловые напряжения). URL: http:/gcon.pstu.ac.ru/ pedsovet/programm/-section=13_8.htm (дата обращения: 07.12.2020).

11. Ягупов В.В., Свистун В.І. Компетентісний підхід до підготовки фахівців у системі вищої освіти. Наукові записки. Педагогічні, психологічні науки та сочіальна робота. Київ : Нац. ун-т «Києво-Могилянська академія», 2007. Т. 71. С. 3-8.

12. Turning Education Structures in Europe. URL: http://tuning. unideusto.org. (Last accessed: 08.12.2020).

\section{REFERENCES}

1. Aleksjuk A.M. (1998). Pedaghoghika vyshhoji osvity Ukrajiny. Istorija. Teorija : pidruchnyk [Pedagogy of higher education in Ukraine. History. Theory: textbook]. Kyjiv : Lybidj. 560 p. [in Ukrainian].

2. Zdorovegha V. (2004). Jevropejsjkyj vybir: shho braty z mynulogho, a chogho vchytysja ukrajinsjkym ZMI [European choice: what to take from the past and what to learn from the Ukrainian media]. About journalism and journalists: articles, essays, speeches. Ljviv : VC LNU im. I. Franka. Vol. 3 (27). 141 p. [in Ukrainian].

3. Klepko S.F. (2006). Filosofija osvity v jevropejsjkomu konteksti : monoghrafija [Philosophy of education in the European context: a monograph]. Poltava : POIPPO. 328 p. [in Ukrainian].

4. Kompetentnisnyj pidkhid u suchasnij osviti: svitovyj dosvid ta ukrajinsjki perspektyvy [Competence approach in modern education: world experience and Ukrainian perspectives]. / za zagh. red. O.V. Ovcharuk. Kyjiv : K.I.S., 2004. 112 p. [in Ukrainian].

5. Osvitnjo-profesijna proghrama vyshhoji osvity pershogho (bakalavrsjkogho) rivnja ghaluzi znanj 06 "Zhurnalistyka" specialjnosti 061 "Zhurnalistyka" [Educational and professional program of higher education of the first (bachelor's) level of knowledge 06 "Journalism" specialty 061 "Journalism"]. Zaporizhzhja : Klasychnyj pryvatnyj universytet, 2018. URL: http://virtuni.education.zp.ua/info_cpu/ node/2742 (Last accessed: 05. 12.2020) [in Ukrainian] .

6. Osvitnjo-profesijna proghrama vyshhoji osvity drughogho (maghistersjkogho) rivnja ghaluzi znanj 06 "Zhurnalistyka" specialjnosti 061 "Zhurnalistyka" [Educational and professional program of higher education of the second (master's) level of the field of knowledge 06 "Journalism" specialty 061 "Journalism"]. Zaporizhzhja : Klasychnyj pryvatnyj universytet, 2018. URL: http://virtuni.education. zp.ua/info_cpu/node/2742 (Last accessed: 05. 12.2020) [in Ukrainian].

7. Roghova T.V. (2004). Rozvytok profesijno-pedaghoghichnoji kompetentnosti vchytelja: metodychnyj aspekt [Development of professional and pedagogical competence of a teacher: methodical aspect]. Means of educational and research work. Vol. 21. P. 197-206 [in Ukrainian].

8. Sorokina Gh. (2009). Formuvannja funkcionaljnykh kompetentnostej majbutnikh fakhivciv zv'jazku [Formation of functional competencies of future communication specialists]. Higher Education. Vol. 12. P. 34-39 [in Ukrainian].

9. Sysoev V.V., Sysoev I.V. (2006). Teoreticheskie osnovy psikhologii upravleniya : uchebnoe posobie [Theoretical foundations of management psychology: a tutorial]. Moskva : Izd-vo SGU. P. 394 [in Russian].

10. Taizova O.S. Kompetentsiya (osnovnye smyslovye napryazheniya) [Competence (main semantic tensions)]. URL: http://gcon.pstu.ac.ru/pedsovet/programm/-section=13_8.htm (Last accessed: 07. 12.2020) [in Russian].

11. Jaghupov V.V., Svystun V.I. (2007). Kompetentisnyj pidkhid do pidghotovky fakhivciv u systemi vyshhoji osvity [Competent approach to training in higher education]. Proceedings. Pedagogical, psychological sciences and social work. Kyjiv : Nac. un-t «Kyjevo-Moghyljansjka akademija». T. 71. P. 3-8 [in Ukrainian].

12. Turning Education Structures in Europe. URL: http://tuning. unideusto.org (Last accessed: 08. 12.2020). 